\title{
EDITORIAL \\ Another good year for the Journal of Management Control: an editorial
}

\author{
Thomas W. Guenther ${ }^{1}$ iD
}

(c) Springer-Verlag GmbH Germany, part of Springer Nature 2019

Looking back on 2018, the last year was an excellent year for the Journal of Management Control. Our journal is still growing on its intended path to become a widely accepted, reputational and distinguished journal in the special field of management accounting and control. In 2018, we achieved an all-time peak of 64 submissions. The average number of days between the date of the receipt of the manuscript and the first decision (submission to first decision) is still low with 69 days. The editors are convinced that this number should not be lower to give reviewers sufficient time to deliver good feedbacks alongside to their main jobs at their affiliations. Even if the historic origin of our journal was German, the journal is truly international with more than $75 \%$ of submissions from international scholars and corresponding authors from 25 different countries all over the world. First round rejection rate is only 50\%, which shows that editors tend to give the authors a chance to revise and resubmit their paper if they see a perspective to finally get an excellent paper contributing to research and practice.

Also in 2018, a large group of distinguished colleagues supported the Journal of Management Control with their expertise and scarce time by reviewing the increasing number of papers. We are very thankful for this outstanding and very valuable resource (reviews finished in the calender year of 2018):

\begin{tabular}{llll}
\hline Title & Last name & First name & Affiliation \\
\hline Prof. Dr. & Becker & Sebastian & HEC Paris, France \\
Dr. & Bedford & David & University of Technology Sydney, Australia \\
Jun.-Prof. Dr. & Bellora-Bienengräber & Lucia & University of Hamburg, Germany \\
Prof. Dr. & Bisbe Vinas & Josep & ESADE Business School, Spain \\
Prof. Dr. & Brueggen & Alexander & Maastricht University, The Netherlands \\
Prof. Dr. & Busco & Christiano & $\begin{array}{c}\text { Universita degli Studi Sociali Guido Carli } \\
\end{array}$ \\
\end{tabular}

$凶$ Thomas W. Guenther

thomas.guenther@tu-dresden.de

1 Technische Universität Dresden, Dresden, Germany 


\begin{tabular}{|c|c|c|c|}
\hline Title & Last name & First name & Affiliation \\
\hline Dr. & Carr & Michelle & University College Cork, Ireland \\
\hline Prof. Dr. & Crasselt & Nils & Bergische Universität Wuppertal, Germany \\
\hline Prof. Dr. & D’Arcy & Anne & Wirtschaftsuniversität Wien, Austria \\
\hline PD Dr. & Derfuss & Klaus & FernUniversität Hagen, Germany \\
\hline Prof. Dr. & Dierkes & Stefan & $\begin{array}{l}\text { Georg-August-Universität Göttingen, } \\
\text { Germany }\end{array}$ \\
\hline Prof. Dr. & Endenich & Christoph & ESSEC Business School, France \\
\hline Dr. & Endrikat & Jan & Technische Universität Dresden, Germany \\
\hline Prof. Dr. & Feldhues & Melanie Lucia & Copenhagen Business School, Danmark \\
\hline Dr. & Fuhrmann & Stephan & Technische Universität Dresden, Germany \\
\hline Prof. Dr. & Goetze & Uwe & Technische Universität Chemnitz, Germany \\
\hline Prof. Dr. & Goretzki & Lukas & Handelshogskolan i Stockholm, Sweden \\
\hline Prof. Dr. & Guenther & Thomas & Technische Universität Dresden, Germany \\
\hline Prof. Dr. & Harris & Elaine & University of Roehampton, UK \\
\hline Dr. & Haustein & Ellen & University of Rostock, Germany \\
\hline Prof. Dr. & Herzig & Christian & University of Kassel, Germany \\
\hline Prof. Dr. & Hiebl & Martin & University of Siegen, Germany \\
\hline Prof. Dr. & Himme & Alexander & Kuehne Logistics University, Germany \\
\hline Prof. Dr. & Hirsch & Bernhard & $\begin{array}{l}\text { Universität der Bundeswehr München, } \\
\text { Germany }\end{array}$ \\
\hline Prof. Dr. & Hoffmann & Stefan & $\begin{array}{l}\text { Christian-Albrechts-Universität zu Kiel, } \\
\text { Germany }\end{array}$ \\
\hline Dr. & Ilg & Patrick & Technische Universität Dresden, Germany \\
\hline Prof. Dr. & Jordan & Silvia & University of Innsbruck, Austria \\
\hline Dr. & Kaufmann & Wesley & Tilburg University, Belgium \\
\hline Prof. Dr. & Knauer & Thorsten & Ruhr University of Bochum, Germany \\
\hline Prof. Dr. & Kruis & Anne-Marie & $\begin{array}{l}\text { Nyenrode Business Universiteit, The } \\
\text { Netherlands }\end{array}$ \\
\hline Prof. Dr. & Kunz & Jennifer & Universität Augsburg, Germany \\
\hline Prof. Dr. & Lachmann & Maik & Technische Universität Berlin, Germany \\
\hline Prof. Dr. & Linder & Stefan & ESSEC Business School, France \\
\hline Prof. Dr. & Loy & Thomas & University of Bayreuth, Germany \\
\hline Prof. Dr. & Lukka & Kari & University of Turku, Finland \\
\hline Dr. & Madini & Paola Maria & University of Kent, UK \\
\hline Prof. Dr. & Mahlendorf & Matthias & $\begin{array}{l}\text { Frankfurt School of Finance and Management, } \\
\text { Germany }\end{array}$ \\
\hline Dr. & Malagueno & Ricardo & University of East Anglia, UK \\
\hline Prof. Dr. & Messner & Martin & University of Innsbruck, Austria \\
\hline Prof. Dr. & Nijhof & André & $\begin{array}{l}\text { Nyenrode Business Universiteit, The } \\
\text { Netherlands }\end{array}$ \\
\hline Dr. & Nitzl & Christian & $\begin{array}{l}\text { Universität der Bundeswehr München, } \\
\text { Germany }\end{array}$ \\
\hline
\end{tabular}




\begin{tabular}{|c|c|c|c|}
\hline Title & Last name & First name & Affiliation \\
\hline Prof. Dr. & Ott & Christian & EM Strasbourg Business School, France \\
\hline Prof. Dr. & Pellinen & Jukka & University of Jyväskylä, Finland \\
\hline Prof. Dr. & Quinn & Martin & Queens University Belfast, UK \\
\hline Prof. Dr. & Reimer & Marko & $\begin{array}{l}\text { WHU - Otto Beisheim School of Management, } \\
\text { Germany }\end{array}$ \\
\hline Prof. Dr. & Schäffer & Utz & $\begin{array}{l}\text { WHU - Otto Beisheim School of Management, } \\
\text { Germany }\end{array}$ \\
\hline Dr. & Schrack & Daniela & Johannes Kepler University Linz, Austria \\
\hline Prof. Dr. & Schreck & Philipp & $\begin{array}{l}\text { Martin-Luther-Universität Halle-Wittenberg, } \\
\text { Germany }\end{array}$ \\
\hline Dr. & Schwering & Anja & Ruhr-Universität Bochum, Germany \\
\hline Prof. Dr. & Sommer & Friedrich & University of Bayreuth, Germany \\
\hline Prof. Dr. & Strauss & Erik & Universität Witten/Herdecke, Germany \\
\hline Prof. Dr. & Stumpf-Wollersheim & Jutta & TU Bergakademie Freiberg, Germany \\
\hline Prof. Dr. & Tillema & Sandra & University of Groningen, The Netherlands \\
\hline Prof. Dr. & Trapp & Rouven & University of Ulm, Germany \\
\hline Prof. Dr. & van der Kolk & Berend & IE Business School, Spain \\
\hline Prof. Dr. & Velte & Patrick & Universität Lüneburg/Leuphana, Germany \\
\hline Prof. Dr. & Verbeeten & Frank & University of Amsterdam, the Netherlands \\
\hline Prof. Dr. & Wentges & Paul & University of Ulm, Germany \\
\hline
\end{tabular}

On behalf of both the authors and the editors, we appreciate the reviewers' guidance for the papers, which the authors might not like at first place, but which helps them in the end and improves the quality of most of the papers.

The Journal of Management Control is open-minded regarding methods and topics, but rigorous in the scope on management accounting and management control. The second issue of 2019 stands for these aims and the scope of our journal.

Thomas Gackstetter, Benedikt Müller-Stewens und Klaus Möller present based on a cross-sectional survey of 59 firms an investigation of the effect of formal and informal controls on the information quality of accounting processes in finance departments. Formal controls are further differentiated in process and output controls whereas peer pressure and the work environment capture the informal controls. Using partial least square structural equation modelling the authors are able to underline the role of informal controls in accounting processes and find evidence for complementary and substitutive effects of formal and informal controls in the accounting function when examining combined effects.

The second paper of Carl Deschamps is a case study of a large Belgian public organization where performance management is a core philosophy. The author examines based on data from observations and interviews of managers the preferences of managers regarding the use of management controls at every hierarchical level and how changes in use affect strategic alignment.

The change to the business partner role has been discussed now for some years in practice. Bo Karlsson, Anders Hersinger and Monika Kurkkio investigate in a mining 
company how it is possible to explain the prevalence of hybrid accountants in management accounting practice, despite the persuasive characteristics of the business partner role. Hybrid accountants are characterized by a combination of traditional and business partner traits. Based on institutional theory the authors suggest that institutional drivers, which shape the role of the practicing actors, exist in every organization.

Finally, Timur Pasch presents a survey study based on 244 firms from Germanspeaking countries using structural equation modelling to explore the mediating role of management accountants and management accounting systems' use for the relationship of differentiation strategy and exploratory innovation. The author finds that that management accounting departments can be part of the strategy implementation mechanism in firms that emphasize exploratory innovation.

The readership of this issue of the Journal of Management Control may be inspired by these four papers and we hope that the authors can contribute to expand our knowledge in management accounting and control for both practice and research.

Dresden, July 2019

For the team of editors

Thomas W. Guenther

Managing editor

Publisher's Note Springer Nature remains neutral with regard to jurisdictional claims in published maps and institutional affiliations. 